\title{
HUBUNGAN GERAKAN BERULANG LENGAN DENGAN TERJADINYA NYERI BAHU PADA PENATA RAMBUT DI SALON
}

\author{
${ }^{1}$ Steicy N. Lumunon \\ ${ }^{2}$ Lidwina Sengkey \\ ${ }^{2}$ Engeline Angliadi
}

\author{
${ }^{1}$ Kandidat Skripsi Fakultas Kedokteran Universitas Sam Ratulangi Manado \\ ${ }^{2}$ Program Studi Ilmu Kedokteran Fisik dan Rehabilitasi Fakultas Kedokteran \\ Univeristas Sam Ratulangi Manado \\ Email: slumunon11_214@yahoo.co.id
}

\begin{abstract}
Every human being has his/her own activity or job. Higher demand jobs need higher responsibilities of its workers. For instance, hair dressers have to do their job by using their arms with repetitive movements that can result in a shoulder pain. This study aimed to identify the relationship between repetitive hand movements and shoulder pain of salon hairdressers. This was an analytical observational study with a cross sectional design. There were 30 respondents obtained by using the purposive sampling method. The chi square test showed that there was no relationship between repetitive arm movements and shoulder pain among salon hairdressers viewed from the period of working and the pain level $(\mathrm{P}=0.800)$ as well as viewed form the hairdresser's height and pain level $(P=0.080)$. Conclusion: There was no significant relationship between the repetitive arm movements and shoulder pain among the salon hairdressers.
\end{abstract}

Keywords: repetitive arm movement, shoulder pain, salon hair dresser

\begin{abstract}
Abstrak: Setiap individu tidak terlepas dari aktifitas ataupun pekerjaan. Semakin tinggi tuntutan pekerjaan semakin besar pula beban pekerjaaan dan aktifitas dari pekerja tersebut. Seperti halnya dengan penata rambut di salon harus melakukan pekerjaannya dengan menggunakan lengan secara berulang yang dapat menimbulkan keluhan nyeri bahu. Penelitian ini bertujuan untuk mengidentifikasi adanya hubungan gerakan berulang lengan dengan terjadinya nyeri bahu pada penata rambut di salon. Penelitian ini menggunakan metode analitik observasional dengan rancangan potong lintang. Sejumlah 30 responden diperoleh dengan menggunakan teknik purposive sampling. Hasil uji Chi square menunjukkan tidak terdapat hubungan antara gerakan berulang lengan dengan terjadinya nyeri bahu pada penata rambut di salon dilihat dari lama kerja responden dan tingkat nyeri $(\mathrm{P}=0,800)$, serta tinggi badan responden dan tingkat nyeri $(\mathrm{P}=$ 0,800). Simpulan: Tidak terdapat hubungan bermakna antara gerakan berulang lengan dan terjadinya nyeri bahu pada penata rambut di salon.
\end{abstract}

Kata kunci: gerakan berulang lengan, nyeri bahu, peneta rambut di salon

Menurut International Association for Study of Pain (IASP), nyeri adalah pengalaman perasaan emosional yang tidak menyenangkan akibat terjadinya kerusakan aktual maupun potensial, atau menggambarkan kondisi terjadinya kerusakan. Nyeri merupakan gejala utama gangguan bahu. ${ }^{1}$
Pergerakan otot-otot harus diimbangi dengan aktivitas baru yang menggantikannya, sehingga darah dapat memasok zat-zat yang diperlukan jaringan tubuh sedangkan zat-zat yang tidak diperlukan diangkut keluar. Gerakan bahu terjadi pada sendi glenohumeral, torakoskapular, 
akromioklavikular, dan sternoklavikular. Sendi glenohumeral merupakan sendi peluru yang terletak di dalam lekuk glenoid yang sangat dangkal. Fungsi sendi ini tergantung pada otot-otot di sekitar lekuk untuk stabilitasinya. Oleh karena itu, banyak gangguan bahu disebabkan oleh gangguan otot dan bukan gangguan tulang atau sendi. $^{2}$

Setiap tahun dalam perawatan primer di Inggris, sekitar 1\% orang dewasa yang berusia $>45$ tahun merupakan kasus baru dari nyeri bahu. Survei di klinik reumatologi berbasis masyarakat di Inggris melaporkan prevalensi nyeri akut sebesar $21 \%$ dengan angka kejadian yang lebih tinggi pada wanita dibandingkan pria yaitu $25 \%$ pada wanita dan $17 \%$ pada pria. ${ }^{3}$

Menurut Depkes RI tahun 2005, 40,5\% pekerja di Indonesia mempunyai keluhan gangguan kesehatan yang berhubungan dengan pekerjaannya dan diantaranya ialah gangguan otot rangka sebanyak $16 \%{ }^{4}$

Nyeri bahu merupakan masalah umum. Pada orang-orang yang berisiko tinggi terjadinya nyeri bahu yaitu mereka yang bekerja sebagai kasir, pekerja garmen, tukang las, tukang batu, dan yang bekerja di industri daging. Penata rambut, pekerja perakitan, pengepakan, dan orang-orang yang bekerja selama berjam-jam di depan komputer, seperti sekretaris dan programer, juga berisiko tinggi terjadinya nyeri bahu. ${ }^{4}$

\section{METODE PENELITIAN}

Penelitian ini menggunakan metode analitik observasional dengan rancangan potong lintang. Penelitian ini dilakukan pada bulan Oktober sampai Desember 2014 di beberapa salon yaitu Manado Town Square, Mega Mall, dan Pasar 45. Sampel diambil secara purposive sampling. Responden ialah penata rambut yang aktif bekerja. Data dianalisis dengan menggunakan SPSS versi 21

\section{HASIL PENELITIAN DAN BAHASAN}

Terdapat 30 penata rambut yang aktif dengan menggunakan lengan secara berulang. Berdasarkan karakteristik jenis kelamin, responden terdiri dari 13 orang laki-laki (43,3\%) dan 17 orang perempuan (56,7\%).

Nyeri adalah pengalaman sensori dan emosional yang tidak menyenangkan akibat dari kerusakan jaringan yang aktual atau potensial. Nyeri sangat mengganggu dan menyulitkan lebih banyak orang dibanding penyakit manapun. ${ }^{5}$ Faktor yang memengaruhi terjadinya nyeri yang tersering ialah faktor usia dan aktifitas yang berlebihan dimana tendon menjadi lemah sehingga lebih rentan mengalami cedera dan peradangan. ${ }^{6}$

Dari 30 responden yang diteliti, 24 responden (80\%) mengalami nyeri $<1$ bulan dengan dan 6 responden (20\%) yang mengalami nyeri 1-3 bulan. Hal ini mugkin disebabkan karena penelitian dilakukan pada saat mendekati hari raya sehingga jumlah pelanggan meningkat dan mengalami nyeri lebih dari biasanya. Juga terdapat perbedaan antara penata rambut yang telah bekerja selama 1-5 tahun dengan yang telah bekerja 6-10 tahun. Pekerja dengan masa kerja $>6$ tahun telah lebih lama merasakan nyeri. Dengan demikian, responden terbanyak mengalami nyeri akut tetapi kebanyakan responden tidak menghiraukan rasa nyeri karena kesibukan bekerja. Menurut Sidharta, nyeri akut adalah nyeri yang mengalami penyembuhan $\leq 2$ minggu; nyeri subakut adalah nyeri yang mengalami penyembuhan $\geq 12$ minggu; sedangkan nyeri kronik adalah nyeri yang tetap berlanjut walaupun diberi pengobatan dan nyeri tidak memiliki makna biologik. ${ }^{7}$

Hasil analisis data menunjukkan bahwa tidak terdapat hubungan antara gerakan berulang lengan dengan terjadinya nyeri bahu pada pekerja salon. Keluhan tersebut dikelompokkan sebagai keluhan sementara/reversibel yaitu nyeri yang terjadi pada saat pembebanan namun akan segera hilang bila pembebanan dihentikan. ${ }^{8}$ Hal tersebut sesuai dengan pernyataan sebagian besar (25 responden, 83,3\%) merasakan nyerinya hilang saat istirahat, dan hanya 5 responden (16,7\%) yang merasakan nyeri tidak hilang saat istirahat $(16,7 \%)$. 
Jurnal e-Clinic (eCl), Volume 3, Nomor 3, September-Desember 2015

Tabel 1. Karakteristik Responden Berdasarkan Tingkat Nyeri

\begin{tabular}{|c|c|c|c|c|c|c|c|c|}
\hline \multirow[t]{3}{*}{ Variabel } & \multicolumn{7}{|c|}{ Tingkat Nyeri } & \\
\hline & \multirow{2}{*}{ Ketegori } & \multicolumn{2}{|c|}{ Nyeri sedang } & \multicolumn{2}{|c|}{ Nyeri berat } & \multicolumn{2}{|c|}{ Total } & \multirow{5}{*}{$P=0,567$} \\
\hline & & $\mathrm{N}$ & $\%$ & $\mathrm{~N}$ & $\%$ & $\mathrm{~N}$ & $\%$ & \\
\hline Jenis kelamin & Laki-laki & 13 & 43,3 & 0 & 0 & 13 & 43,3 & \\
\hline \multirow[t]{2}{*}{ Total } & Perempuan & 16 & 53,3 & 1 & 3,3 & 17 & 56,7 & \\
\hline & & 29 & 96,7 & 1 & 3,3 & 30 & 100 & \\
\hline \multirow[t]{2}{*}{ Umur } & 20-30 thn & 14 & 46,7 & 1 & 3,3 & 15 & 50 & \multirow{3}{*}{$P=0,500$} \\
\hline & $31-40$ thn & 15 & 50 & 0 & 0 & 15 & 50 & \\
\hline Total & & 29 & 96,7 & 1 & 3,3 & 30 & 100 & \\
\hline \multirow{3}{*}{$\begin{array}{l}\text { Lama Kerja per } \\
\text { hari }\end{array}$} & $<10 \mathrm{jam} / \mathrm{hr}$ & 23 & 76,7 & 1 & 3,3 & 24 & 80 & \multirow{3}{*}{$P=0,800$} \\
\hline & $\geq 10 \mathrm{jam} / \mathrm{hr}$ & 6 & 20,0 & 0 & 0 & 6 & 20 & \\
\hline & Total & 29 & 96,7 & 1 & 3,3 & 30 & 100 & \\
\hline \multirow{10}{*}{$\begin{array}{l}\text { Lama kerja per } \\
\text { tahun }\end{array}$} & 1 tahun & 1 & 3,3 & 0 & 0 & 1 & 3,3 & \multirow[t]{10}{*}{$\mathrm{P}=0,317$} \\
\hline & 2 tahun & 5 & 16,7 & 0 & 0 & 5 & 16,7 & \\
\hline & 3 tahun & 2 & 6,7 & 1 & 3,3 & 3 & 10 & \\
\hline & 4 tahun & 3 & 10 & 0 & 0 & 3 & 10 & \\
\hline & 5 tahun & 8 & 26,7 & 0 & 0 & 8 & 26,7 & \\
\hline & 6 tahun & 3 & 10 & 0 & 0 & 3 & 10 & \\
\hline & 7 tahun & 2 & 6,7 & 0 & 0 & 2 & 6,7 & \\
\hline & 9 tahun & 3 & 10 & 0 & 0 & 3 & 10 & \\
\hline & 10 tahun & 2 & 6,7 & 0 & 0 & 2 & 6,7 & \\
\hline & Total & 29 & 96,7 & 1 & 3,3 & 30 & 100 & \\
\hline \multirow[t]{6}{*}{ Jumlah Pelanggan } & $<5$ & 1 & 3,3 & 0 & 0 & 1 & 3,3 & \multirow[t]{6}{*}{$\mathrm{P}=0,989$} \\
\hline & $5-10$ & 22 & 73,3 & 1 & 3,3 & 23 & 76,6 & \\
\hline & $11-15$ & 2 & 6,7 & 0 & 0 & 2 & 6,7 & \\
\hline & $16-20$ & 1 & 3,3 & 0 & 0 & 1 & 3,3 & \\
\hline & $>20$ & 3 & 10 & 0 & 0 & 3 & 10 & \\
\hline & Total & 29 & 96,7 & 1 & 3,3 & 30 & 100 & \\
\hline \multirow[t]{3}{*}{ Tinggi Badan } & $\leq 105 \mathrm{~cm}$ & 6 & 20 & 0 & 0 & 6 & 20 & \multirow[t]{3}{*}{$P=0,800$} \\
\hline & $>150 \mathrm{~cm}$ & 23 & 76,7 & 1 & 3,3 & 24 & 80 & \\
\hline & Total & 29 & 96,7 & 1 & 3,3 & 30 & 100 & \\
\hline
\end{tabular}

\section{SIMPULAN}

Berdasarkan hasil penelitian dapat disimpulkan bahwa tidak terdapat hubungan antara gerakan berulang lengan dengan terjadinya nyeri bahu pada penata rambut di salon di kota Manado.

\section{SARAN}

1. Bagi penata rambut: Hasil penelitian ini dapat menjadi bahan pertimbangan, menambah wawasan dan informasi bagi penata rambut dalam mencegah risiko akibat pekerjaan setiap hari dan memperhatikan jam kerja perhari sesuai dengan ketentuan yang berlaku.

2. Bagi Institusi pendidikan: Hasil peneltian ini dapat digunakan untuk menambah pengetahuan sebagai bahan informasi dan edukasi untuk mencegah terjadinya nyeri bahu akibat gerakan berulang lengan.

\section{DAFTAR PUSTAKA}

1. International Assocation for Study of Pain. IASP taxonomy. IASP website [Online] 1979. [Cited 2014 Sept]. Available from: http://www.iasppain.org/Conten/Navig ationMenu/GeneralResourceLinks/Pain Definitions/default.htm.

2. Swartz MH. Buku Ajar Diagnostik Fisik. Edisi bahasa Indonesia. Jakarta: EGC, 1995.

3. Murphy R, Carr A. Am Fam Physician. 2011;83(2):137-8.

4. Departeman Kesehatan RI. Direktorat Bina 
Kesehatan Kerja, Direktorat Jenderal Bina Kesehatan Masyarakat. Strategi Nasional Kesehatan Kerja. Indonesia, 2007

5. Smeltzer SC. Keperawatan Medikal Bedah Brunner dan Suddart Vol 2 (Edisi 8). Jakarta: Buku kedokteran, 2001.

6. Anonymous. Faktor Resiko Nyeri Bahu. Available

from: penyebab-nyeri-punggung-atas-danbahu-tulang-belikat.

7. Sidharta P. Neurologi Klinis Dalam Praktek Umum. Jakarta: Dian Rakyat, 2009.

8. Gerakan berulang atas. Available from http://repository.usu.ac.id/bitstream/12 3456789/17022/6/Chapter\%20I.pdf

http://www.amazine.co/23181/19- 